\title{
Erratum
}

\section{Ancient imperial heritage and Islamic universal historiography: al-Dīnawarī's secular perspective}

\author{
Hayrettin Yücesoy \\ Journal of Global History (2007) 2, pp. 135-155
}

Unfortunately the following acknowledgement was omitted from the title page of the above article:

I am grateful to John Carrol, William G. Clarence-Smith, Fred Donner, Ahmet Karamustafa, Damien Smith, Warren Treadgold, the editors and the anonymous reviewers of the JGH for their comments and suggestions.

The publisher would like to apologise for this error and any confusion caused. 